Egyptian Journal of Aquatic Biology \& Fisheries

Zoology Department, Faculty of Science,

Ain Shams University, Cairo, Egypt.

ISSN $1110-6131$

Vol. 23(4): 539 - 549 (2019)

www.ejabf.journals.ekb.eg

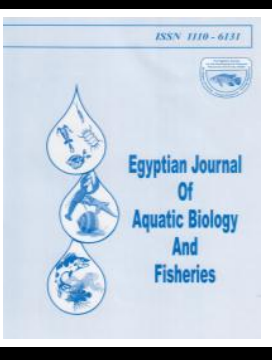

\title{
Spatial and temporal variations of heavy metals accumulation in some macroalgal flora of the Red Sea
}

\author{
Amany G. Madkour*, Sara H. Rashedey and Mahmoud A. Dar \\ National Institute of Oceanography and Fisheries, Egypt \\ *Corresponding author: dramanymadkour@yahoo.com
}

\section{ARTICLE INFO \\ Article History: \\ Received: Sept. 1, 2019 \\ Accepted: Oct. 28, 2019 \\ Online: Nov. 2019}

Keywords:

Macroalgae

Heavy metals

Bioaccumulation

metals pollution

Red Sea

\begin{abstract}
The average contents of $\mathrm{Zn}, \mathrm{Cd}, \mathrm{Cu}, \mathrm{Co}, \mathrm{Fe}, \mathrm{Mn}$ and $\mathrm{Ni}$ were measured seasonally in the ashes of Caulerpa racemosa, Cystoseira myrica, Digenea simplex, Hormophysa cuneiformis, Padina pavonica and Sargassum cinereum using Flame Atomic Absorption Spectrometry (AAS). The studied species were collected from three different sites along the northern part of the Red Sea coast during 2017. Cystoseira myrica recorded the highest $\mathrm{Fe}$ average $(575.88 \mu \mathrm{g} / \mathrm{g}$ dry wt.) and Mn (164.12 $\mu \mathrm{g} / \mathrm{g}$ dry wt.) in summer at Site II, Caulerpa racemosa recorded the highest $\mathrm{Cu}$ average $(91.10 \mu \mathrm{g} / \mathrm{g}$ dry wt.) at Site I in autumn, meanwhile Sargassum cinereum showed the highest averages of $\mathrm{Zn}$ and $\mathrm{Co}$ (33.88 and $16.56 \mu \mathrm{g} / \mathrm{g}$ dry wt.) in spring at sites II and III respectively. The highest averages Ni and Cd (10.46, $2.05 \mu \mathrm{g} / \mathrm{g}$ dry wt.) were observed in Padina pavonica at Site III in summer and spring seasons respectively. The obtained data indicated that the studied macroalgae have significant differential abilities to accumulate a certain heavy metals under the local conditions and it can be used as a good target for monitoring metals pollution in marine waters.
\end{abstract}

\section{INTRODUCTION}

The contamination of water with heavy metals is quite critical issue causing many problems all over the world. The toxicity of these metals in reducing growth of plants and development of microorganisms, which seriously harm the health of animals and humans.

Macroalgae have the capability of filtering some metals as; zinc, cadmium, copper, nickel and iron and some potential carcinogens from the surrounding seawater. Subsequently; they have the ability to remove the toxic heavy metals and accumulate them in high concentrations within their body cells reach $4 \times 10^{3}$ to $20 \times 10^{3}$ times higher than the surrounding seawater (Torres et al., 2008). Several works have demonstrated that macroalgae can be used to partly strip heavy metal in the marine waters (El-Manawy et al., 2005; Mohamed and Mohamed, 2007; Ginneken and de Vries, 2018).

Accumulation of heavy metals by macroalgae has been shown to occur in two phases (Murphy, 2007). The first is a rapid surface reaction where physical and chemical interaction takes place among the metal and the surface polysaccharides of the algae, complexation, adsorption and ion-exchange occur. The second phase is described by a much slower heavy metal uptake over a period of hours. Some factors affecting on bio-sorbents such as the physiological state of the algae, the availability 
of micronutrients throughout their growth, the age of the cells and finally the environmental conditions during uptake as temperature, light intensity and $\mathrm{pH}$ (Murphy, 2007). Because of the bio-monitors like seaweeds are efficient in reporting measurable bioavailable concentrations of the contaminants, the present work aims to measure the differential abilities of macroalgal to accumulate certain heavy metals under the local conditions.

\section{MATERIALS AND METHODS}

\section{Study Area}

The study area included three sites along the northern part of the Red Sea coast under different natural and anthropogenic effluents. Site (I) is located in front of the National Institute of oceanography and Fisheries (NIOF). It is characterized by the widely distributed reef flats that extended for about $5 \mathrm{~km}$ seaward and including many diving sites and many coastal lagoons with depth variation between 1.5 and $6 \mathrm{~m}$. The inshore zone of this site suffers from extensively high sedimentation rates throughout the year and underground wastewater seepage. Site (II) is located about $77 \mathrm{~km}$ to the south of Hurghada City at $17 \mathrm{~km}$ south of Safaga in the mangrove forest. This site is distinguished by mangrove trees and shrubs of Avicenna marina and extended tidal zone $(400 \mathrm{~m})$ formed from the raised Quaternary terrace disrupted by sand patches overlying by the mangrove trees near the coastline. This site is highly affected by; the landfilling from the phosphate shipment, the effect of shipyard and many other human activities from Safaga harbor, fishing and other coastal activities. Site (III) is located in the downstream of Wadi Gasus (Magic Life Kalawy Resort) at about 40km northern Qusier City. Tidal zone is rocky formed from the raised coral terrace with small sand zone near the coastline. The tidal flat has kidney shape extended for 100 to $150 \mathrm{~m}$ with water depth ranged between 0.50 and $5.00 \mathrm{~m}$., this site is impacted by the temporary flashfloods and tourist activities (Figure 1).

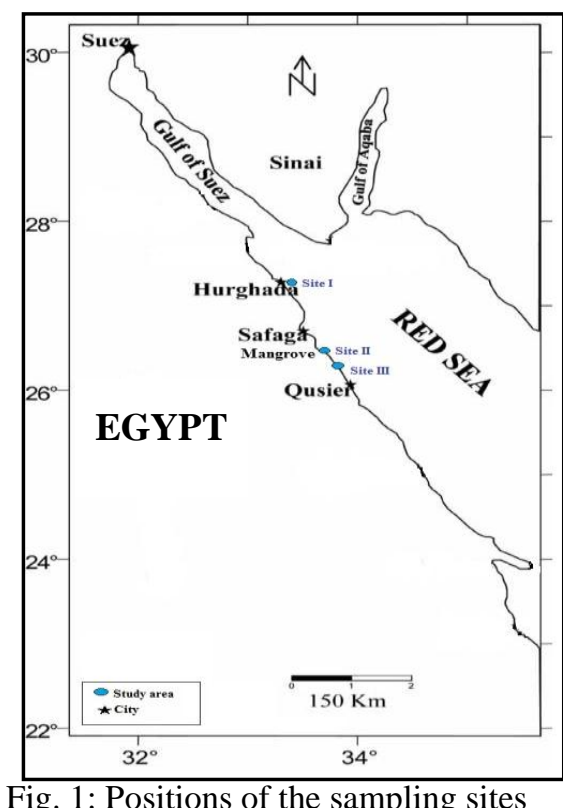

\section{Samples Collection and preparation}

Six species of macroalgae belonging to three families were collected seasonally from the selected sites in period between autumn 2016 and summer 2017 including; 
Caulerpa racemosa var. gracilis (Zanardini) Weber-van Bosse belongs Chlorophyta, Cystoseira myrica (Gmelin) C. Agardh, Hormophysa cuneiformis (Gmelin) Silva, Padina pavonica Alender\& Kraft, and Sargassum cinereum (Turner) C. Agardh belonging Phaeophyta and Digenea simplex (Wulfen) C. Agardh from Rhodophyta (plate1). The algae were identified by morphological characters using taxonomic references (Aleem, 1978; Coppejans and Beeckman, 1990 and Sahoo, 2001). The collected samples were cleaned in the field as possible with seawater then the samples were packed in polyethylene bags containing seawater from the local environment and transferred to the laboratory after a few hours. At the laboratory, the samples were cleaned again by tap water followed by distilled water to remove any agglutinated materials as; the epiphytes, sand or mud particles. The selected specimens were oven dried at $105^{\circ} \mathrm{C}$ for $48 \mathrm{~h}$ to remove excess water and moister, cooled, weighted, and then ashed at $475^{\circ} \mathrm{C}$ in a muffle furnace for $24 \mathrm{~h}$ (Fuge and James, 1973).
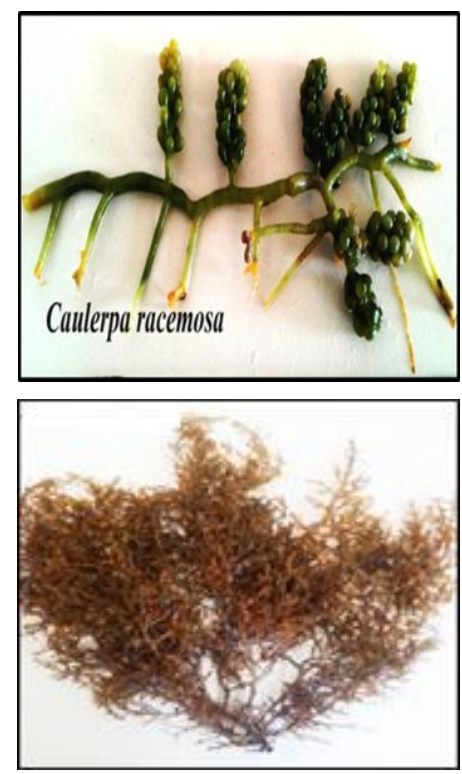

Cystoseira myrica
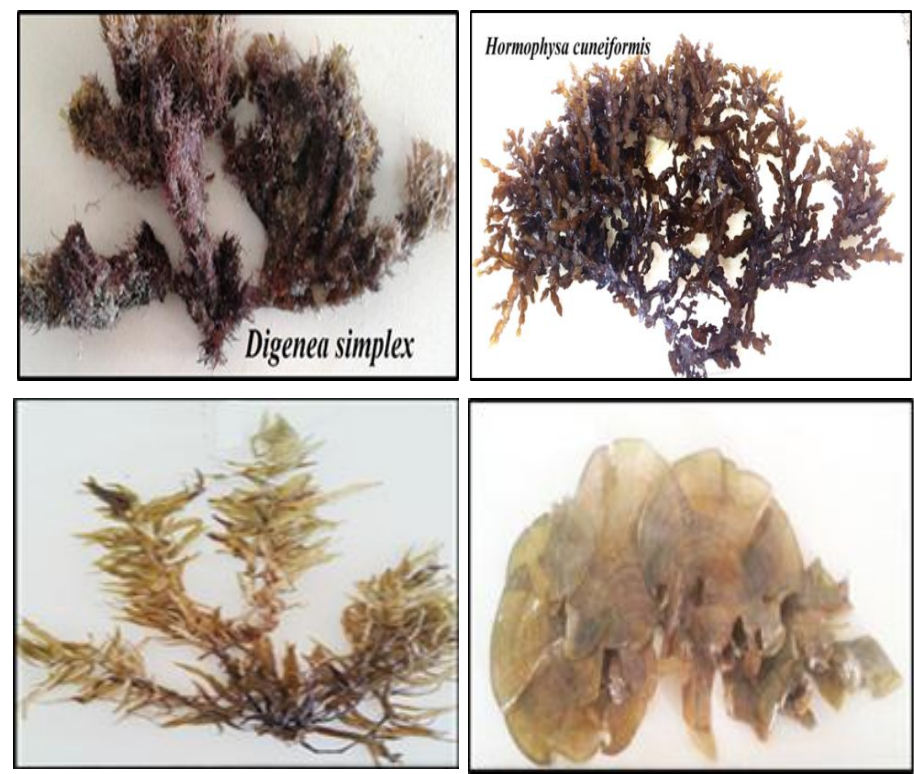

Sargassum cinereum

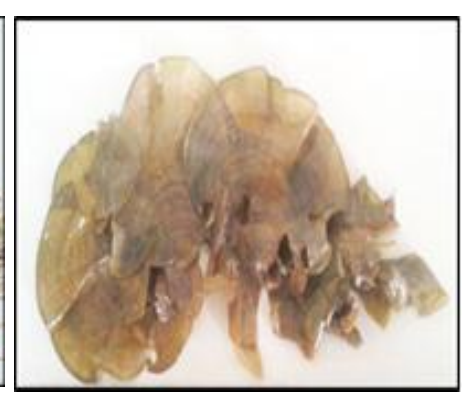

Padina pavonica

plate1: The six selected macroalgae species during survey.

\section{Heavy metals determination}

Accurately, $10 \mathrm{ml}$ of aqua regia $\left(2.5 \mathrm{ml}\right.$ of $16 \mathrm{M} \mathrm{HNO}_{3}$ and $7.5 \mathrm{ml}$ of $\left.16 \mathrm{M} \mathrm{HCl}\right)$ were added to $0.5 \mathrm{~g}$ of each ashed sample in the conical flask and kept at room temperature overnight. Then the solution was digested on a hotplate $\left(80^{\circ} \mathrm{C}\right)$, evaporated to near dryness and allowed to cool at room temperature. The digested samples were diluted with distilled water, filtered with Whatman filter paper to remove the solid residuals and diluted again accurately to $25 \mathrm{ml}$. Finally; the heavy metals; $\mathrm{Fe}, \mathrm{Mn}, \mathrm{Cu}, \mathrm{Zn}, \mathrm{Co}, \mathrm{Ni}$ and $\mathrm{Cd}$ in the extracts were analyzed using atomic absorption spectrophotometer (GBC-932AA) at the National Institute of Oceanography and Fisheries, Red Sea Branch. Three technical replicates of each measurement were applied with differences less than $3 \%$ to obtain the maximum accuracies.

\section{Analysis of physico-chemical parameters}

Water temperature $\left({ }^{\circ} \mathrm{C}\right)$, salinity $(\mathrm{ppt}), \mathrm{pH}$ value and dissolved oxygen $(\mathrm{mg} / \mathrm{L})$ were determined from the average of three readings at each site by the multiparameter instrument (YSI ProODO Instrument). Turbidity (NTU) was measured by turbidity- 
meter (LaMotte 2020e). Sedimentation rate $\left(\mathrm{gm} . \mathrm{cm}^{-2} \cdot \mathrm{day}^{-1}\right)$ was determined by the method of Gardner, 1980.

\section{Statistical analysis}

The spatial and temporal variability are illustrated by Boxplots graph and the statistical significance of these variations is illustrated by two-way ANOVA. All statistical tests were performed using Minitab ${ }^{\circledR}$ (Version 16) software.

\section{RESULTS AND DISCUSSION}

\section{Heavy metal concentration in the selected macroalgae}

As shown in Table 1, Sargassum cinereum showed the highest averages of $\mathrm{Zn}$ (33.88 $\mu \mathrm{g} / \mathrm{g}$ dry wt.) in spring and the highest average of $\mathrm{Cu}(91.1 \mu \mathrm{g} / \mathrm{g}$ dry wt.) in summer at site II. Also it recorded the highest average of Co $(16.56 \mu \mathrm{g} / \mathrm{g}$ dry wt.) at site III in spring. The highest average of Fe was recorded in Cystoseira myrica $(557.88 \mu \mathrm{g} / \mathrm{g}$ dry wt.) at Site II in summer, while the highest annual mean (439.81 $\mu \mathrm{g} / \mathrm{g}$ dry wt.) was in Digenea simplex. Padina pavonica recorded the highest averages of $\mathrm{Cd}, \mathrm{Ni}$ and $\mathrm{Mn}(2.05,10.46,164.12 \mu \mathrm{g} / \mathrm{g}$ dry wt.) at site III in spring and summer and the highest annual mean of $\mathrm{Cd}(1.22 \mu \mathrm{g} / \mathrm{g}$ dry wt.), while Digenea simplex recorded the highest annual mean of $\mathrm{Ni}(5.01 \mu \mathrm{g} / \mathrm{g}$ dry wt.), Digenea simplex, Caulerpa racemosa and Padina pavonica recorded the highest annual means of $\mathrm{Zn}$, $\mathrm{Cu}$, Co and $\mathrm{Mn}(9.38,22.80$ and $4.55,47.89 \mu \mathrm{g} / \mathrm{g}$ dry wt. respectively). The concentration of $\mathrm{Zn}$ may be attributed or controlled by activators of dehydrogenases and protein-synthesis enzymes in these species (Besada et al., 2009). Foster, 1976 found that macroalgae tend to accumulate $\mathrm{Zn}$ within their tissues much more than $\mathrm{Cd}$ due to the competition for binding sites. The competition between metals for algal sites could decrease the accumulation of those elements which exhibited lower concentration levels in environment (water or sediment) or which are present in less available forms (e.g. Cd). The accumulation of $\mathrm{Co}$ in macroalgae tissue might be due to the physiological participation of $\mathrm{Co}$ in the certain enzymes.

The highest concentrations of $\mathrm{Cu}$ in marine plants can be attributed to the fact that it is important micronutrient for various metabolic functions of the plants (Donat and Dryden 2001). The levels of the accumulated copper in the algal tissues indicated the lipid body of the plant cell. The high concentrations of $\mathrm{Cu}$ are causing a great dinger to the marine organisms including; fish, crustaceans, phytoplankton and zooplankton, algae and filter feeders. $\mathrm{Zn}$ enhances the catalytic, structural and regulatory functions, stabilizes membranes, hormones and nucleic acids (Norziah and Ching, 2000). $\mathrm{Cu}$ and $\mathrm{Zn}$ accumulations in the studied species at the different sites and seasons are much more than $\mathrm{Cd}$ that may be attributed the species ability to assimilate both metals within their tissues much more $\mathrm{Cd}$.

Fe showed the highest concentrations followed by $\mathrm{Mn}$ in the different species relative to the other metals may attribute to the high bio-availability in both fine particulate sediments and the surrounding aquatic environment. Several factors such as human activities, natural inputs and abilities of algal species to biomagnifying $\mathrm{Fe}$ from the surrounding environment lead to the bio-availability of $\mathrm{Fe}$ and $\mathrm{Mn}$ in high levels. Occurrence of higher concentration of $\mathrm{Mn}$ in plants is a common feature for maintaining osmotic balance, ion regulation and for enzyme catalysis (Clarkson and Hanson, 1980). The heavy metal accumulations in the sampled macroalgae species showed significant variation from species to another indicating to the differential capability of these species to accumulate the heavy metals from the surrounding aquatic environment. 
Table 1: Average and annual concentration of heavy metals ( $\mu \mathrm{g} / \mathrm{g}$ dry wt.) in macroalgal species at different sites and seasons

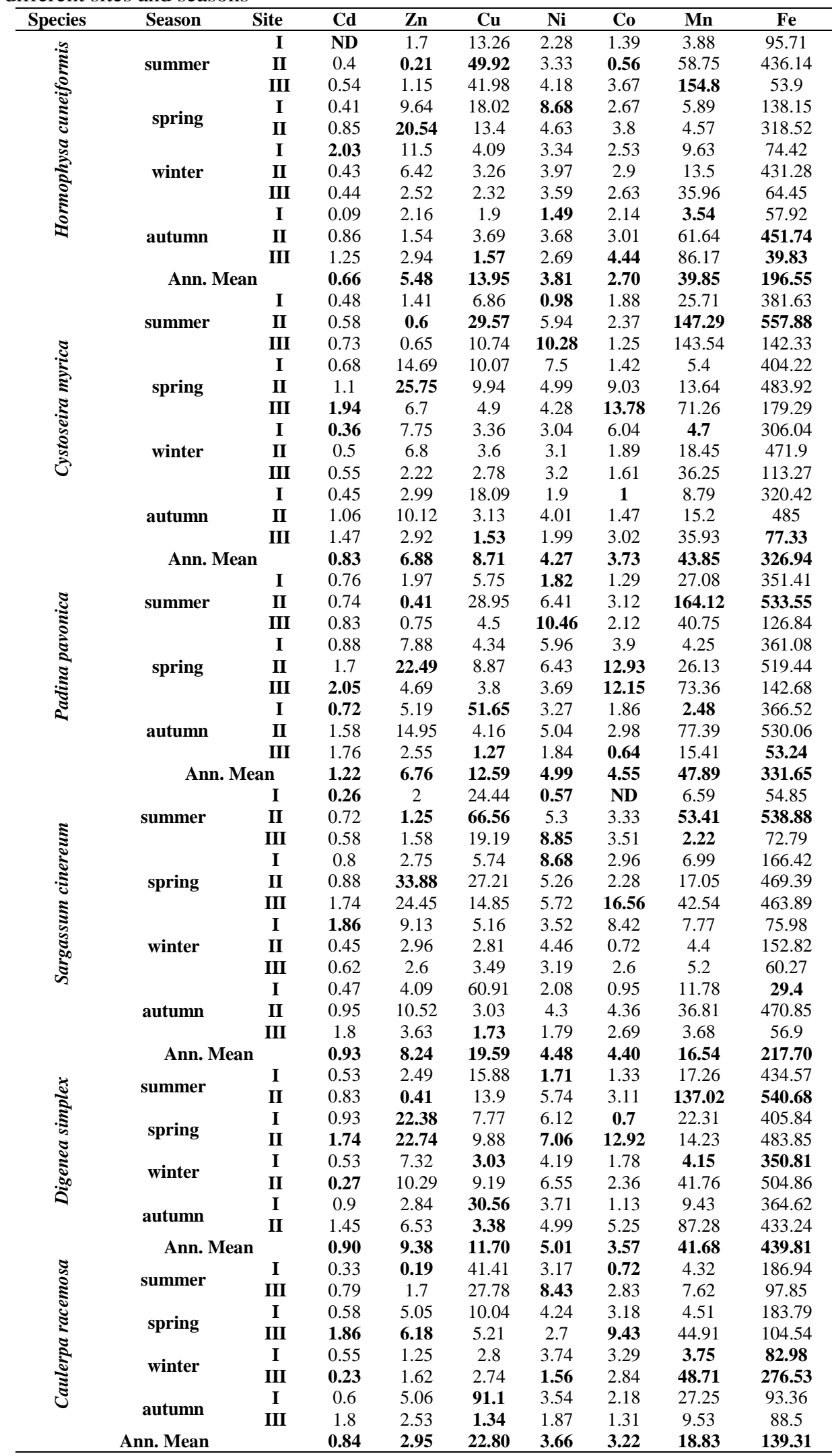

ND: Not Detected

Vymazal (1995) suggested that the accumulation of metals depend on the type of polysaccharides in the algae and since various elements have different 
electronegativity (tends to accept electrons) probably this may effects on the metals uptake in algae at different levels. He attributed the variations in the metals contents in the seaweeds to the different metals electronegativity (e.g. $\mathrm{Fe}, \mathrm{Ni}$ and $\mathrm{Cu}$ ). Billah et al. (2017) documented that the concentrations of heavy metals in algal tissues are varied among macroalgal species, probably due to of the differences of structure, age, and growth of thallus among macroalgal species. Levels of heavy metals in Red Sea macroalgae and other tropical locations worldwide comparing to background concentrations are listed in Table 2.

Table 2: Levels of heavy metals ( $\mu \mathrm{g} / \mathrm{g}$ dry wt.) in Red Sea macroalgae and other tropical locations worldwide comparing to background concentrations

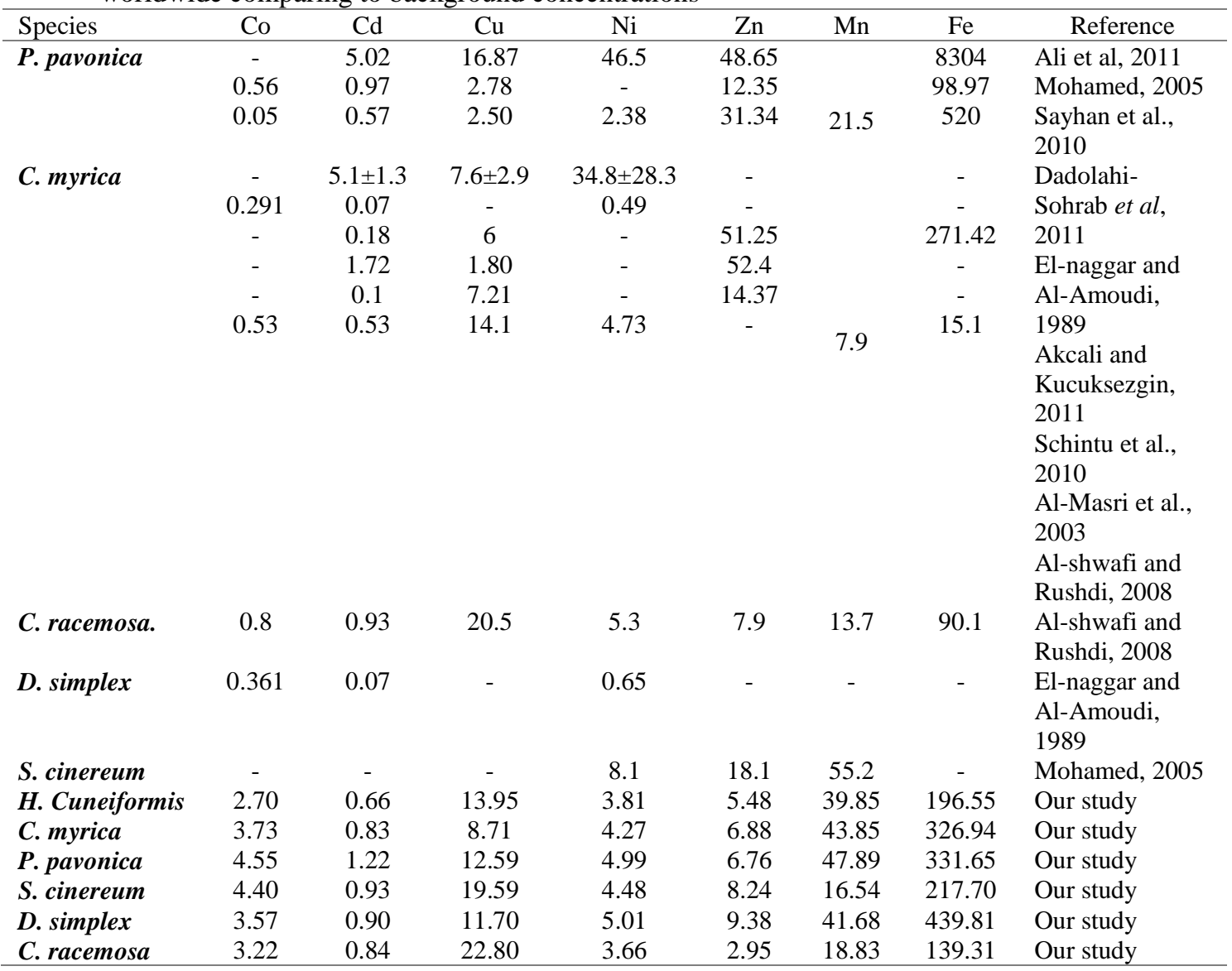

\section{Physico-chemical parameters}

Physico-chemical parameters of the Red Sea influence the composition and the structure of the existing macroalgal communities including surface water temperature, light intensity and salinity (Osman and Mohammed, 2016). At the same time Murphy, 2007 reported that, environmental conditions like temperature, salinity and $\mathrm{pH}$ are one of the factors that effect on metal uptake by macroalgae.

As shown in Table 3, the costal water temperature varied between a minimum of $17.7{ }^{\circ} \mathrm{C}$ in winter at St. II and a maximum of $31.8^{\circ} \mathrm{C}$ in summer at the same station. The $\mathrm{pH}$ values were found on the alkaline side with a maximum of 8.2 at St. II in summer and autumn and a minimum of 7.7 at St. III in spring. Water turbidity was varied between sites and seasons, the highest average was 38.3 NTU recoded in autumn at site II, while the lowest average was $0.6 \mathrm{NTU}$ recorded in summer at site III. Like turbidity, mangrove area (site II) had the highest average of sedimentation 
rate $\left(0.010 \mathrm{~g} . \mathrm{cm}^{-2} \cdot \mathrm{day}^{-1}\right)$ in autumn, while the lowest average $0.002 \mathrm{~g} . \mathrm{cm}^{-2} . \mathrm{day}^{-1}$ was recorded in summer at site III.

Dissolved oxygen of seawater was varied among $5.1 \mathrm{mg} / \mathrm{L}$ in summer at site I and $7.3 \mathrm{mg} / \mathrm{L}$ in winter at the same site. Salinity was varied between sites and seasons, where the highest average (44.2 ppt) was recorded in summer at site II and the lowest average (40.5 ppt) was recoded in autumn at site II.

Table 3: Seasonal fluctuations of the physico-chemical parameters in the studied area during 2016- 2017

\begin{tabular}{cccccccc}
\hline site & Season & $\begin{array}{c}\text { Temperature } \\
\left({ }^{\mathbf{0}} \mathbf{C}\right)\end{array}$ & $\begin{array}{c}\text { Turbidity } \\
(\mathbf{N T U})\end{array}$ & $\begin{array}{c}\text { Salinity } \\
(\mathbf{p p t})\end{array}$ & $\begin{array}{c}\text { DO } \\
(\mathbf{m g} / \mathbf{L})\end{array}$ & pH & $\begin{array}{c}\text { Sed. rate } \\
\left(\mathbf{g m . c m}^{-2} . \mathbf{d a y}\right.\end{array}$ \\
\hline \multirow{4}{*}{ I } & Autumn & $21.3 \pm 0.1$ & $3.7 \pm 0.38$ & $41.1 \pm 0.13$ & $6.5 \pm 0.2$ & $7.9 \pm 0.008$ & $0.004 \pm 0.001$ \\
& Winter & $20.9 \pm 0.02$ & $8.9 \pm 1.4$ & $42.3 \pm 0.3$ & $7.3 \pm 0.1$ & $7.9 \pm 0.008$ & $0.005 \pm 0.001$ \\
& Spring & $29.03 \pm 0.2$ & $5.5 \pm 0.3$ & $41.1 \pm 0.01$ & $6.8 \pm 0.1$ & $7.9 \pm 0.01$ & $0.003 \pm 0.002$ \\
& Summer & $30.4 \pm 0.09$ & $2.3 \pm 0.04$ & $43.2 \pm 0.04$ & $5.1 \pm 0.04$ & $7.89 \pm 0.01$ & $0.003 \pm 0.002$ \\
II & Autumn & $24.5 \pm 0.07$ & $38.3 \pm 9.5$ & $40.5 \pm 0.08$ & $5.5 \pm 0.1$ & $8.2 \pm 0.03$ & $0.010 \pm 0.001$ \\
& Winter & $17.7 \pm 0.1$ & $7.2 \pm 1.5$ & $41.7 \pm 0.08$ & $7.2 \pm 0.1$ & $7.9 \pm 0.01$ & $0.008 \pm 0.001$ \\
& Spring & $27.3 \pm 0.1$ & $5.1 \pm 0.5$ & $41.3 \pm 0.1$ & $5.2 \pm 0.2$ & $8.0 \pm 0.1$ & $0.007 \pm 0.001$ \\
& Summer & $31.8 \pm 0.2$ & $3.9 \pm 1.3$ & $44.2 \pm 0.08$ & $5.7 \pm 0.04$ & $8.2 \pm 0.01$ & $0.005 \pm 0.002$ \\
III & Autumn & $23.6 \pm 0.1$ & $6.1 \pm 1.4$ & $41.2 \pm 0.1$ & $5.5 \pm 0.2$ & $8.1 \pm 0.02$ & $0.003 \pm 0.001$ \\
& Winter & $20.3 \pm 0.1$ & $8.7 \pm 2$ & $42.4 \pm 0.05$ & $6.7 \pm 0.1$ & $7.8 \pm 0.01$ & $0.007 \pm 0.001$ \\
& Spring & $29.3 \pm 1$ & $4.6 \pm 1$ & $41.5 \pm 0.1$ & $6.7 \pm 0.1$ & $7.7 \pm 0.1$ & $0.005 \pm 0.001$ \\
& Summer & $30.4 \pm 0.08$ & $0.6 \pm 0.2$ & $42.7 \pm 0.08$ & $5.5 \pm 0.4$ & $7.9 \pm 0.1$ & $0.002 \pm 0.001$ \\
\hline
\end{tabular}

Each value is the average \pm SD

\section{Spatial and seasonal variation of heavy metals in the tested seaweed}

The spatial and temporal variability of heavy metals in the investigated algae are illustrated by boxplots (Fig.2) and the statistical significance of these variations is assembled in Table 4.

As shown by boxplots (Fig. 2-a), $\mathrm{Zn}$ in studied species was varied from 33.88 $\mu \mathrm{g} / \mathrm{g}$ dry wt. at site II in spring to $0.19 \mu \mathrm{g} / \mathrm{g}$ dry wt. at site II in summer. Plots of spring showed long tails with a large box area above median indicating to that the data configuration is skewed towards the high values during this season. Co in the tested algae (16.56 $\mu \mathrm{g} / \mathrm{g}$ dry wt.) was recorded at site III during spring, while it was reached $0.56 \mu \mathrm{g} / \mathrm{g}$ dry wt. at site I in summer. Site II showed the highest variability (large box length) in spring and site III recorded the lowest variability in winter. All plots of the studied sites and seasons showed long tails with a large box area under the median indicating to that the values of $\mathrm{Co}$ in the selected species skewed towards low concentration during all seasons except at sites I, III in spring and site I in winter (Fig. 2-b). $\mathrm{Cu}$ in the investigated species was largely varied between $91.10 \mu \mathrm{g} / \mathrm{g}$ dry wt. at site I and $1.27 \mu \mathrm{g} / \mathrm{g}$ dry wt. at site III with the highest variability at site I and the lowest variability at site III during autumn. (Fig. 2-c).

The investigated macroalgae species showed Cd values between $2.05 \mu \mathrm{g} / \mathrm{g}$ dry wt. at site III in spring and undetected at site I in autumn. The highest median of Cd $(0.94 \mu \mathrm{g} / \mathrm{g}$ dry wt.) was illustrated by line (in center of box) meanwhile highest variability was observed in autumn at site III compared with other sites (Fig. 2-d). Ni was varied between $10.46 \mu \mathrm{g} / \mathrm{g}$ dry wt. in the tested species at site III and $0.57 \mu \mathrm{g} / \mathrm{g}$ dry wt. at site I in summer. Site II in the same season, plots of site II in winter and autumn have a long tail with a large box area above the median, which means that the studied macroalgae in this sites have high concentrations of nickel (Fig. 2-e).

The highest $\mathrm{Fe}(557.88 \mu \mathrm{g} / \mathrm{g}$ dry wt. $)$ in the studied species was recorded at site II in summer and the lowest one $(29.40 \mu \mathrm{g} / \mathrm{g}$ dry wt. $)$ was showed at site I in autumn. 
The highest variability of Fe in tested algae was found at site I during summer, while the lowest fluctuation was occurred at site III during autumn. Plots of winter showed longer tails than other seasons with large box area above the median indicating to that the $\mathrm{Fe}$ distribution is skewed toward high concentration during this season (Fig. 2-f). Mn in the studied species was varied between $164.12 \mu \mathrm{g} / \mathrm{g}$ dry wt. at site II during summer and $2.22 \mu \mathrm{g} / \mathrm{g}$ dry wt. at site I during autumn. Summer season showed long tails with large box area above the median at sites I and III, this indicate that the underlying distribution is skewed towards high values during this season (Fig. $2-g)$.
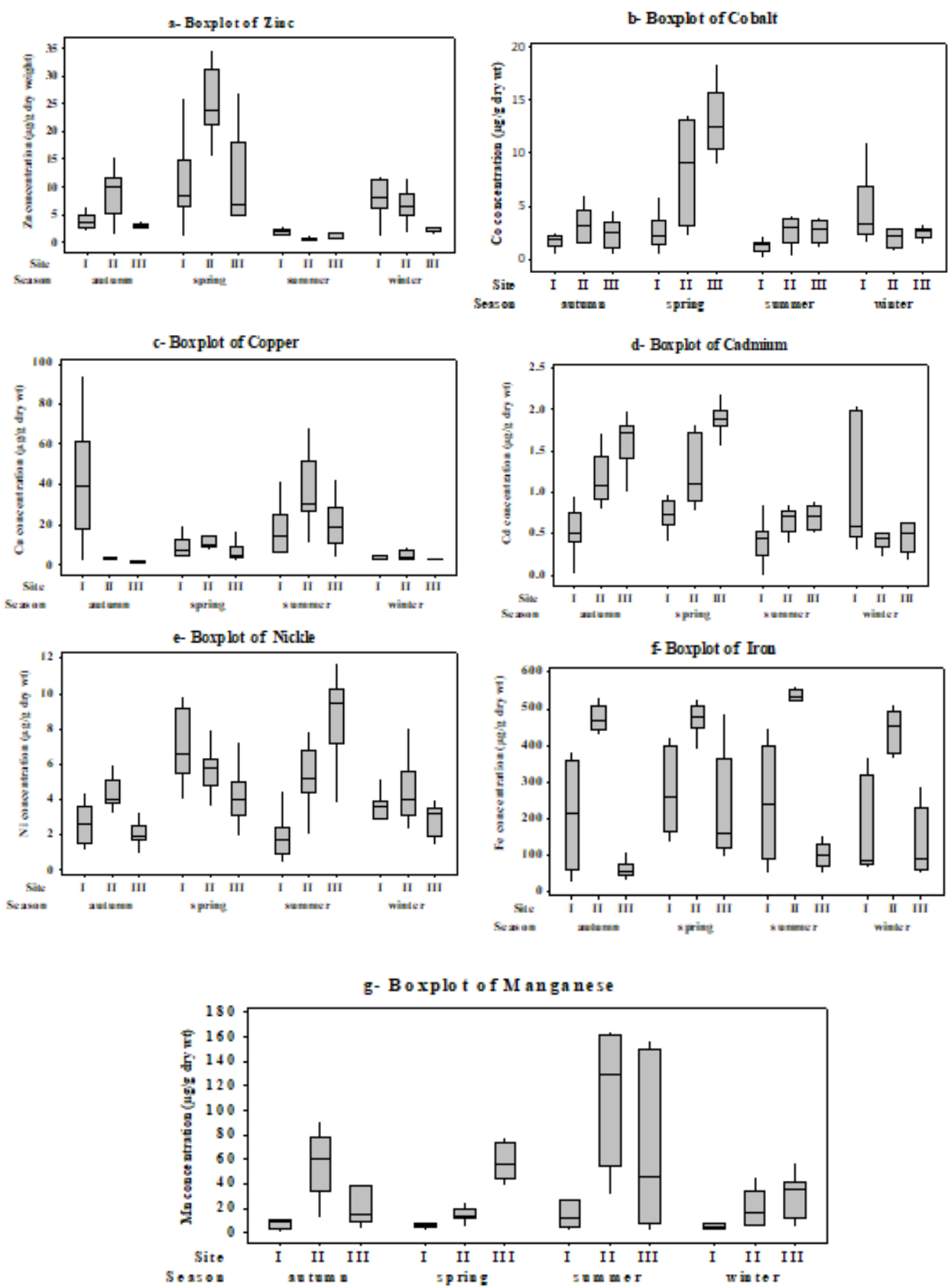

Fig. 2: Boxplot graph for spatial and temporal variation in heavy metals of investigated macroalgae at different sites and seasons.

In general boxplot showed high variation in heavy metal concentrations of selected macroalgae among the studied sites and seasons which was supported by the statistical using Two-Way ANOVA $(\mathrm{P}<0.001)$ for sites and seasons (Table 4). 
Obvious spatial variations in heavy metal contents of the investigated algal species were observed during this study. Mangrove (Site II) had the highest level of most heavy metals followed by Magic (Site III). Site II was highly affected by the anthropogenic activities from the northern shipment operations in addition to natural inputs from the temporary flashfloods. Abdallah and Abdallah (2008) found significant variation in the heavy metal contents from species to another and from site to another according to the local conditions as; anthropogenic and natural inputs, tidal range, seawater temperature, salinity regimes, dissolved nutrients, type of tissue, age of plant, its nutritional history and the morphological structure of the studied areas. Clear seasonal fluctuations in the heavy metal contents of tested macroalgae were observed. The obtained results indicated that the highest levels of studied metals in algal tissues were occurred in spring and summer while lowest levels were observed in winter that may attributed to the rates of growth for the different species, whereas the highest flourishing of the studied species at the investigated sites were observed in summer.

Table 4: Two way ANOVA showing variations in metals between sites and seasons

\begin{tabular}{ccccc}
\hline \multirow{2}{*}{ Metals } & \multicolumn{3}{c}{$\mathbf{F}$} & \multicolumn{2}{c}{$\mathbf{P}$} \\
\cline { 2 - 5 } & Site & Season & Site & Season \\
\hline Cd & 21.75 & 23.61 & $<0.0001$ & $<0.0001$ \\
$\mathbf{Z n}$ & 23.17 & 66.11 & $<0.0001$ & $<0.0001$ \\
$\mathbf{C u}$ & 6.93 & 14.30 & 0.002 & $<0.0001$ \\
$\mathbf{N i}$ & 6.17 & 16.08 & 0.003 & $<0.0001$ \\
$\mathbf{C o}$ & 15.42 & 34.07 & $<0.0001$ & $<0.0001$ \\
$\mathbf{M n}$ & 30.96 & 15.77 & $<0.0001$ & $<0.0001$ \\
$\mathbf{F e}$ & 129.52 & 4.88 & $<0.0001$ & 0.003 \\
\hline
\end{tabular}

\section{CONCLUSIONS}

The present outcomes demonstrated exceptionally variety in substantial metal concentrations of chose macroalgae among the examined location and seasons. Iron, manganese and zinc recorded the highest accumulation in the studied species. Mangrove (Site II) had the largest accumulation of most substantial metals pursued by Magic (Site III). The macroalgae in studied area contribute competently for removal of heavy metals from the water. Many species have high capacity for absorption of certain metals, making them good bioremediators.

\section{REFERENCES}

Abdallah, M. and Abdallah, A. (2008). Biomonitoringstudy of heavy metals in biota and sediments in the South Eastern coast of Mediterranean Sea. Environment and Monitoring Assessment, 146(1-3): 139-145. https://doi.org/10.1007/s10661-007-0066-8

Akcali, I. and Kucuksezgin, F. (2011). A biomonitoring study: heavy metals in macroalgae from eastern Aegean coastal areas. Mar. Pollut. Bull., 62(3): 637645. https://doi.org/10.1016/j.marpolbul.2010.12.021

Aleem, A.A. (1978). A preliminary list of algae from Sierra Leone. Bot. Mar., 21: 397-399.

Al-Masri, M.S.; Mamish, S. and Budier, Y. (2003). Radionuclides and trace metals in eastern Mediterranean Sea algae. J. Environ. Radioact., 67(2): 157-168. 
Al-Shwafi, N.A. and Rushdi, A.I. (2008). Heavy metal concentrations in marine green, brown, and red seaweeds from coastal waters of Yemen, the Gulf of Aden. Environmental Geol., 55(3): 653-660. https://doi.org/10.1007/s00254-007-1015-0

Besada, V.; Andrade, J.M.; Schultze, F. and Gonzalez, J.J. (2009). Heavy metals in edible seaweeds commercialized for human consumption. J. Mar. Syst., 75: 305-313. https://doi.org/10.1016/j.jmarsys.2008.10.010

Billah, M.M.; Kamal, A.M.; Idris, M.H. and Ismail, J. (2017). Mangrove Macroalgae as Biomonitors of Heavy Metal Contamination in a Tropical Estuary, Malaysia. Water Air Soil Pollution, 228(9): 347. https://doi.org/10.1007/s11270-017-3500-8

Clarkson, D.T. and Hanson, J.B. (1980). The mineral nutrition of higher plants. Annu. Rev. Plan. Physiol., 31: 231-298.

Coppejans, E. and Beeckman, T. (1990). Caulerpa (Chlorophyta, Caulerpales) from the Kenyan coast. Nova Hed., 50: 111-125.

Dadolahi-Sohrab, A.; Nikvarz, A.; Nabavi, S.M.; Safahyeh, A. and Mohseni, M.K. (2011). Environmental monitoring of heavy metals in seaweed and associated sediment from the strait of Hormuz. Iran World Journal of Fish and Marine Sciences, 3(6): 576-589. ISSN: 2078-4589. https://idosi.org/wjfms/wjfms3(6)11/19.pdf

Donat, J. and Dryden, C. (2001). Transition metals and heavy metal speciation. In: Steele J, Thorpe S, Turekian K (eds) Encyclopedia of ocean sciences. Academic, Elsevier Science, New York, pp. 3027-3035.

El-Manawy, I.M.; El-Sarraf, W.M. and Mourad, F. (2005). Metal levels in common seaweeds from Suez bay. Egyptian J. of Phycol., 6(1): 137-150. ISSN: 11108649. https://www.bibliomed.org/mnsfulltext/167-1466839962.pdf

El-Naggar, M.E.E. and Al-Amoudi, O.A. (1989). Heavy metal levels in several species of marine algae from the Red Sea of Saudi Arabia. J.K.A.U. Science, 1: 5-13. https://doi.org/10.4197/sci.1-1.1

Foster, W. (1976). Concentrations and concentration factors of heavy metals in brown algae. Environmental Pollution, 10: 45-53. https://doi.org/10.1016/00139327(76)90094-X

Fuge, R. and James, K.H. (1973). Trace metal concentrations in brown seaweeds, Cardigan Bay, Wales. Mar. Che., 1(4): 281-293. https://doi.org/10.1016/03044203(73)90018-2

Gardner, W.D. (1980). Sediment trap dynamics and calibration: a laboratory evaluation. J. Mar. Res., 38(1): 17-39. http://images.peabody.yale.edu/publications/jmr/jmr3801-02.pdf

Ginneken, V. and de Vries, E. (2018). Seaweeds as Biomonitoring System for Heavy Metal (HM) Accumulation and Contamination of Our Oceans. American Journal of Plant Sciences, 9: 1514-1530.

Mohamed, A.A. and Mohamed, H.A. (2007). Levels of trace metals in marine macro algae from bitter lakes, Suez Canal, Egypt. Egypt. J. Aquat. Biol. \& Fish., 11: 1-191.

Mohamed, S.F. (2005). Bio monitoring of Heavy Metals in Some Brown Algal Species in the Red Sea area (Saudi Arabia and Egypt). Arab Gulf Journal of Scientific Research., 23(3): 126-131.

Norziah, M.H. and Ching, C.Y. (2000). Nutritional composition of edible seaweed Gracilariachanggi. food Chem., 86: 69-76.

Osman, N.A. and Mohammed S.E. (2016). A compiled checklist of seaweeds of Sudanese Red Sea coast. Journal of Coastal Life Medicine, 4(2): 114-120.

Sahoo, D. (2001). Seaweeds of Indian coast. A.P.H. Publishing Corporation, New Delhi., 283. 
Sayhan Topcuoğlu; Önder Kılıç; Murat Belivermiş; Halim Aytekin Ergül and Gülşah Kalayc1 (2010). Use of marine algae as biological indicator of heavy metal pollution in Turkish marine environment. J. Black Sea/Mediterranean Environment, 16: 43-52.

Schintu, M.; Marras, B.; Durante, L.; Meloni, P. and Contu, A. (2010). Macroalgae and DGT as indicators of available trace metals in marine coastal waters near a lead-zinc smelter. Environ. Monit. Assess., 167: 653-661. https://doi.org/10.1007/s10661-009-1081-8

Torres, M.A.; Barros, M.P.; Sara C.G. Campos; Pinto, E.; Satish R.; Richard T. Sayre and Colepicoloa, Pio. (2008). Biochemical biomarkers in algae and marine pollution: A review. Ecotoxicol. and Environ. Saf., 71(1): 1-15. https://doi.org/10.1016/j.ecoenv.2008.05.009

Vymazal, J. (1995). Algae and element cycling in wet lands. C.R.C. Press, Boca Raton, Lewis Publishers, USA, ISBN: 0873718992 